\title{
Vulnerability of Canadian aquatic ecosystems to nuclear accidents
}

\author{
Lars Brinkmann (D), David J. Rowan
}

Received: 22 August 2017/Revised: 13 November 2017/Accepted: 15 November 2017/Published online: 29 November 2017

\begin{abstract}
Several cesium and strontium bioaccumulation models are used widely in national and international guidance for ecological and human health risk assessments for radiocesium $\left({ }^{134} \mathrm{Cs}\right.$ and $\left.{ }^{137} \mathrm{Cs}\right)$ and radiostrontium $\left({ }^{90} \mathrm{Sr}\right)$, but have not been used to make predictions of radiological risk from nuclear accidents under variable environmental conditions on broad geographical scales. In this paper, we first present models for predicting the bioaccumulation of cesium and strontium by aquatic biota based on ambient concentrations of dissolved potassium and calcium, respectively, and then test these models using independent data from aquatic ecosystems at Canadian nuclear sites. Secondly, models yielding the best predictions across a wide range of input parameters were selected to estimate bioaccumulation factors (BAFs) for cesium and strontium in aquatic ecosystems across Canada, using trophic level of organisms and dissolved potassium for cesium and calcium concentrations for strontium as predictor variables, and presented as contour maps of radiological risk. The models show that risk from bioaccumulation of cesium and strontium can vary by several orders of magnitude depending on site-specific environmental conditions and trophic ecology. Overall, our results suggest that single-parameter approaches taken by regulatory standards may either over- or under-predict radiological risk at many locations, and are thus not readily suitable to inform siting decisions for new nuclear developments.
\end{abstract}

Keywords Bioaccumulation - Cesium .

Nuclear accidents · Risk assessment .

Small modular reactor $\cdot$ Strontium

\section{INTRODUCTION}

An increasing resolve towards lower carbon emission targets has renewed interest in nuclear power in Canada and internationally. In particular, the widespread commissioning of small modular reactors (SMRs) is being explored as a promising option for cost-effective, zero-emission, offgrid power generation, hydrogen production and other purposes in remote northern regions and other locations across Canada (Kessides 2012; Waters and Didsbury 2014). Recent discussions have exposed a number of challenges in regulating such operations, including concerns about environmental risks during routine operations and accidental release situations (CNSC 2016).

In Canada, current regulatory approaches for releases of radionuclides to the environment rely on site-specific data collected at reactor sites (Chant et al. 2000; CSA 2014). For radiocesium in areas away from nuclear reactors, a mean value for freshwater fish was derived from Laurentian Great Lakes basin data in Rowan and Rasmussen (1994), even though the variability in that dataset spanned orders of magnitude. For radiostrontium in areas away from reactors, a single value was adopted from International Atomic Energy Agency (IAEA) TRS 472 (IAEA 2010). For these radionuclides, water chemistry and, for cesium, trophic level have been shown to determine the bioaccumulation among species and systems (Vanderploeg et al. 1975; Rowan and Rasmussen 1994; Rowan et al. 1998; Kryshev 2006; Smith et al. 2009; Pinder et al. 2014, 2016). Models based on these parameters could be used instead of single generic values to predict bioaccumulation and assess ecosystem vulnerability. Models based on the approaches of Vanderploeg et al. (1975), Rowan and Rasmussen (1994), Rowan et al. (1998), Kryshev (2006), and Smith et al. (2009) are presented in TRS 472 (IAEA 2010). However, CSA N288.1-14 (CSA 
2014) no longer uses this approach and neither does ERICA (2015), a commonly used dose assessment tool, where single values lead to over-prediction or under-prediction at many sites. None of the standards (CSA, IAEA TRS-422, 472) provide values for estuarine environments.

The accidents at Chernobyl and Fukushima have shown that radiological releases had far-reaching, pan-jurisdictional consequences for public risk. In the aftermath of Chernobyl, aside from the initial effects of ${ }^{131} \mathrm{I}$, the fission products ${ }^{137} \mathrm{Cs}$ and ${ }^{90} \mathrm{Sr}$ were key long-term contaminants contributing to public dose, due to their abundance, relatively long physical half-lives, solubility, and potential for bioaccumulation. However, risk levels from this release varied considerably on local, regional, and continental scales, due to variability in deposition and ecological factors affecting bioaccumulation (Hakanson et al. 1992).

Radiocesium and radiostrontium were also released during the accident at Fukushima; however, comparatively little was emitted to the atmosphere, fallout over land was localized, and the public was protected by rapid evacuation/exclusion measures. The majority of contamination was released into the Pacific Ocean, where closure of local fisheries mitigated risk to the public from fish consumption in the most contaminated areas near the reactors. Concerns over contaminated fish associated with pan-oceanic dispersion of the Fukushima plume were also raised by jurisdictions in North America; however, due to the effects of dilution and biogeochemical factors, radiological contamination released from Fukushima was shown to pose very low public and environmental health risks in the eastern North Pacific basin (Chen 2013; Neville et al. 2014; Smith et al. 2015).

Sixty years into the age of commercial nuclear energy, numerous reactors in both inland and coastal settings are nearing the end of their designed duty cycle or are already operating beyond their life expectancy. Elevated risks of radiological contamination from aging reactors and increasing decommissioning activities worldwide necessitate risk predictions on broader geographical scales. The European experience post Chernobyl exemplified significant gaps in risk predictions at such scales. Thus, a priori information on risk hot spots must be regarded as crucial to streamline monitoring and mitigation efforts in the eventuality of future accidental releases in Canada and elsewhere.

The bioaccumulation of cesium and strontium in aquatic biota are known to be strongly, inversely dependent on the external concentration of their essential metabolic analogues, potassium $(\mathrm{K})$ and calcium $(\mathrm{Ca})$, respectively. The effect of potassium on the bioaccumulation of cesium occurs as primary producers passively or actively acquire potassium and cesium through potassium ion channels (Rowan and Rasmussen 1994). Thereafter, invertebrates and fish obtain most of their cesium through ingestion of food, and exhibit biomagnification of about 2- to 4-fold with each trophic level
(Rowan and Rasmussen 1994). The models of Rowan and Rasmussen (1994) were developed from freshwater, estuarine, and marine ecosystems and were tested in three subsequent studies of freshwater (Smith et al. 2000; Pinder et al. 2014) and marine (Pinder et al. 2016) fish, and in all instances, were confirmed as providing predictions within about twofold of observations. Twofold variation in bioaccumulation among individual fish species is common within (Rowan 2013; Pinder et al. 2014) and between systems (Pinder et al. 2014).

Biological uptake and tropism of strontium is analogous to the micronutrient calcium, depositing predominantly in calcified structures of animals (Nielsen 2004; Poston and Klopfer 1988). The primary uptake route of strontium and calcium in aquatic biota appears to be direct uptake from water, with ingestion of strontium and calcium in food of secondary importance (Farrell and Campana 1996; Gallahar and Kingsford 1996; Walther and Thorrold 2006). Calcium and strontium enter biota through ion channels of cells, following competitive inhibition kinetics. Thus, cellular uptake of strontium is inversely dependent on external concentrations of calcium and, to a lesser extent, other competing divalent ions (Chowdhury and Blust 2001). Consistent with this, field studies have shown a strong inverse relationship between strontium bioaccumulation and external calcium concentration for fish bone and flesh (Vanderploeg et al. 1975; Kryshev 2006).

In this paper, we first select models for predicting the bioaccumulation of cesium and strontium by aquatic biota, and then test these models using independent data from aquatic ecosystems at Canadian nuclear sites. Based on these tests, we use appropriate models and ambient concentrations of potassium and calcium in surface water, available through Canadian federal and provincial monitoring programs and the published literature, to estimate BAFs for these sites. The results are used to create a cartographic representation of bioaccumulation risk across the Canadian landscape. Finally, we discuss these results in respect to ecosystem vulnerability, pre-accident preparedness, reactor siting, and national and international regulation.

\section{METHODS}

\section{Models for predicting cesium BAFs in fish and invertebrates}

The model selected for predicting cesium BAFs for freshwater, estuarine, and marine fish is adapted from Eq. 2 in Rowan and Rasmussen (1994) with the disequilibrium term removed:

$$
\log \left(\mathrm{Cs} \mathrm{BAF}_{\text {fish }}\right)=5.271-0.549 \times \log [\mathrm{K}]_{\text {water }}+0.488 \times \mathrm{TL},
$$


$r^{2}=0.817, \mathrm{SE}_{\mathrm{est}}=0.309, n=362$,

where $\mathrm{Cs} \mathrm{BAF}_{\text {fish }}$ is the cesium bioaccumulation factor for fish (wet weight, $\mathrm{L} \mathrm{kg}^{-1}$ ), TL is the trophic level of the fish ( 0 for planktivores and benthivores, 1 for omnivores and piscivores), and $[\mathrm{K}]_{\mathrm{water}}$ is the concentration of potassium in water $\left(\mathrm{mg} \mathrm{L}^{-1}\right)$. The disequilibrium term only affected piscivores and omnivores, and its inclusion for systems at steady state is not necessary (Rowan and Rasmussen 1994).

The only general model available for predicting cesium BAFs for freshwater and marine invertebrates is Eq. 7.7 in Whicker et al. (2007):

$\log \left(\mathrm{Cs}_{\mathrm{BAF}} \mathrm{F}_{\text {invertebrate }}\right)=5.036-0.583 \times \log [\mathrm{K}]_{\text {water }}$,

$r^{2}=0.796, \mathrm{SE}_{\text {est }}=0.322, n=60$,

where $\mathrm{Cs} \mathrm{BAF}_{\text {invertebrate }}$ is the cesium bioaccumulation factor for invertebrates (wet weight, $\mathrm{L} \mathrm{kg}^{-1}$ ) and $[\mathrm{K}]_{\text {water }}$ is the concentration of potassium in water $\left(\mathrm{mg} \mathrm{L}^{-1}\right)$.

\section{Data for federal nuclear sites used to test models for predicting Cs BAFs}

Data for federal nuclear sites used to test models for predicting cesium BAFs in fish flesh from Lake Huron, Lake Ontario, Ottawa River, St. Lawrence River, and Bay of Fundy, as well as data for whole fish, invertebrate flesh, and aquatic plants from the Bay of Fundy, were obtained from Chant et al. (2000). Data for whole fish and invertebrates from the Ottawa River were obtained from Rowan et al. (1998, 2013), and Rowan (2013). Data for fish and invertebrates from Lower Bass Lake were obtained from Rowan et al. (1998). Data for fish from the Winnipeg River were obtained from Guthrie et al. $(1986,1974)$.

\section{Models for predicting strontium BAFs for fish}

Smith et al. (2009) tested the models of Vanderploeg et al. (1975) and Kryshev (2006) that predict Sr BAFs for fish from concentrations of Calcium in water. The models of Vanderploeg et al. (1975) included Perch Lake data (Ophel et al. 1971). A simple inverse relationship was developed between whole fish strontium BAF and the calcium concentration of water $\left([\mathrm{Ca}]_{\text {water }}, \mathrm{mg} \mathrm{L}^{-1}\right)$ :

$\mathrm{Sr} \mathrm{BAF}_{\mathrm{wf}, \mathrm{ww}}=3224 /[\mathrm{Ca}]_{\mathrm{water}}$,

$r^{2}=0.81, n=132$,

where $\mathrm{Sr} \mathrm{BAF}_{\mathrm{wf}, \mathrm{ww}}$ is the whole fish strontium BAF (wet weight, $\mathrm{L} \mathrm{kg}^{-1}$ ).

Models for fish bone and fish flesh were presented in Vanderploeg et al. (1975):

$\ln \mathrm{Sr} \mathrm{BAF}_{\mathrm{fb}, \mathrm{dw}}=9.59-1.15 \times \ln [\mathrm{Ca}]_{\mathrm{water}}$, $r^{2}=0.90, n=36$,

$\ln \mathrm{Sr} \mathrm{BAF}_{\mathrm{ff}, \mathrm{ww}}=5.18-1.21 \times \ln [\mathrm{Ca}]_{\text {water }}$,

$r^{2}=0.74, n=19$,

where $\mathrm{Sr} \mathrm{BAF}_{\mathrm{fb}, \mathrm{dw}}$ is the fish bone strontium BAF (dry weight, $\mathrm{L} \mathrm{kg}^{-1}$ ) and $\mathrm{Sr} \mathrm{BAF}_{\mathrm{ff}, \mathrm{dw}}$ is the fish flesh strontium BAF (wet weight, $\mathrm{L} \mathrm{kg}^{-1}$ ), and $[\mathrm{Ca}]_{\text {water }}$ is the calcium concentration of water $\left(\mathrm{mg} \mathrm{L}^{-1}\right)$.

\section{Data for federal nuclear sites used to test models for predicting strontium BAFs}

Data for federal nuclear sites used to test models for predicting strontium BAFs in fish flesh from Lake Huron, Lake Ontario, Ottawa River, St. Lawrence River and Bay of Fundy, as well as data for whole fish from the Bay of Fundy, were obtained from Chant et al. (2000). Data on fish bones were obtained from Lee et al. (2014) for the Ottawa River. Data on whole fish from Perch Lake were obtained from Ophel et al. (1971) and Yankovich et al. (2010), as well as data on fish bones from Ophel et al. (1971). Data for fish bones from the Winnipeg River were obtained from Guthrie et al. (1974, 1986).

\section{Potassium and calcium concentrations in surface water}

The models predicting bioaccumulation factors for cesium and strontium are parameterized with concentrations of dissolved potassium and calcium in ambient surface water. These were obtained from the databases of provincial and federal monitoring programs (queried from British Columbia Ministry of Environment; Quebec, Alberta, Saskatchewan, Manitoba, Environment Canada, Parks Canada, Aboriginal Affairs and Northern Development Canada, IISD-ELA). Data for specific locations were also extracted from published reports and manuscripts (Rowan and Rasmussen 1994; Balasubramaniam et al. 2015; Sonnenberg 2015). Where references did not report specific geographic locations of sampling sites for the purpose of spatial analyses, report data for proximal sites were composited and an approximate centroid location point was determined for the cluster using Google Earth. Water chemistry data were generally limited to the most recent 6 years of measurements (2010-2016), and averaged. For sampling locations in data-sparse geographical regions, measurements dating back to 1970 were included.

\section{Bioaccumulation risk predictions for Canadian aquatic ecosystems}

Bioaccumulation factors for radiocesium in omnivorous/ piscivorous (TL parameter $=1$ ) and non-piscivorous fish 
$(\mathrm{TL}=0)$ were predicted using Eq. (1), assuming steadystate conditions, and for invertebrates using Eq. (2). Bioaccumulation factors for radiostrontium in fish flesh were predicted using a post hoc revised model [Eq. (6)], which yielded improved predictions for calcium concentrations outside of the range of predictor values used to develop earlier models (see "Results and discussion").

Spatial data processing and cartography were performed in Quantum GIS 2.8.1. Bioaccumulation estimates were interpolated spatially using inverse distance weighting with distance coefficient $=2.95$ and an interpolation grid of 1000 by 1000 blocks.

\section{RESULTS AND DISCUSSION}

\section{Bioaccumulation of cesium by fish}

The bioaccumulation of cesium by fish at federal nuclear sites is generally well predicted by Eq. 1 (Table 1; Fig. 1). Three Ottawa River datasets show that means for omnivores and piscivores are all within a factor of 2 of predictions, with percids tending to be higher than predictions, especially below Chalk River Laboratories. Predictions of Eq. (1) are within a factor of 2 for the Lower Bass Lake, Winnipeg River, St. Lawrence River, and Bay of Fundy. Bioaccumulation factors for Lake Ontario piscivores are slightly greater than twofold predictions, and with those from Lake Huron more than fivefold greater than predictions. This may be due to uncertainty in measures of cesium in water (Chowdhury and Blust 2001), but similar bioaccumulation factors for some omnivores and piscivores from these systems were observed earlier (Rowan and Rasmussen 1994).

Predictions from Eq. (1) are within about twofold of observations for planktivores and benthivores from the Ottawa River, Lower Bass Lake, Winnipeg River, St. Lawrence River, and Bay of Fundy (Table 1; Fig. 1). Once again, fish BAFs from Lakes Huron and Ontario are more than about fourfold greater than model predictions (Table 1; Fig. 1), and may reflect underestimations of concentrations in water (Chant et al. 2000), but similar bioaccumulation factors for some benthivores and planktivores from these

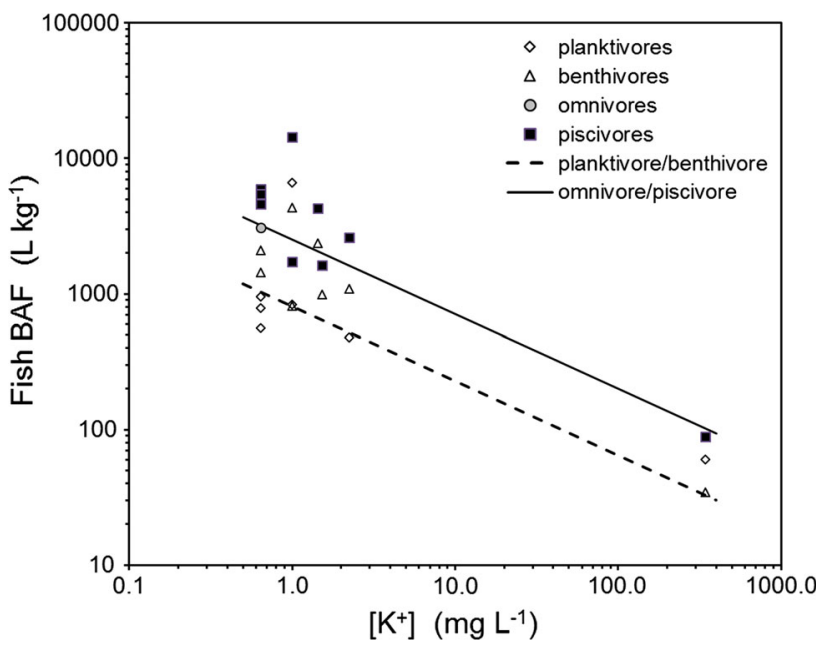

Fig. 1 Bioaccumulation of cesium by fish at federal nuclear sites as a function of dissolved potassium, with Eq. (1) predictions plotted for planktivores/benthivores and omnivores/piscivores

Table 1 Cesium bioaccumulation factors BAFs $\left(\mathrm{L} \mathrm{kg}^{-1}\right)$ for fish from ecosystems with federal nuclear sites compared to predictions from Eq. (1). Observations are in good agreement with predictions (within twofold) except for Lake Huron and Lake Ontario, where concentrations of cesium in water are uncertain

\begin{tabular}{|c|c|c|c|c|c|c|c|}
\hline \multirow[t]{2}{*}{ Lake } & \multirow[t]{2}{*}[\mathrm{K}]{$\left(\mathrm{mg} \mathrm{L}^{-1}\right)$} & \multicolumn{6}{|l|}{ Cesium BAFs } \\
\hline & & Omnivores & Piscivores & Equation (1) & Planktivores & Benthivores & Equation (1) \\
\hline Ottawa River ${ }^{\mathrm{a}}$ & 0.64 & $3097 \pm 300$ & $4607 \pm 357$ & 3198 & $957 \pm 97$ & $2090 \pm 207$ & 1040 \\
\hline Ottawa River ${ }^{b}$ & 0.64 & $5094 \pm 813$ & $5938 \pm 219$ & 3198 & $784 \pm 53$ & & 1040 \\
\hline Ottawa River ${ }^{c}$ & 0.64 & $5800 \pm 2800$ & $5480 \pm 530$ & 3198 & $560 \pm 20$ & $1430 \pm 160$ & 1040 \\
\hline Perch Lake & 1.5 & & & 2002 & & & 651 \\
\hline Lower Bass Lake & 1.0 & & $1726 \pm 30$ & 2501 & $836 \pm 65$ & $818 \pm 70$ & 813 \\
\hline Winnipeg River & 2.2 & & $2598 \pm 344$ & 1611 & 477 & $1087 \pm 148$ & 524 \\
\hline Lake Huron & 1.0 & & $14375 \pm 924$ & 2501 & $6600 \pm 812$ & $4333 \pm 471$ & 813 \\
\hline Lake Ontario & 1.4 & & $4267 \pm 165$ & 2046 & & $2370 \pm 130$ & 665 \\
\hline St. Lawrence River & 1.5 & & $1615 \pm 118$ & 1978 & & $992 \pm 82$ & 643 \\
\hline Bay of Fundy & 343 & & $89 \pm 4$ & 101 & $60 \pm 5$ & $35 \pm 2$ & 33 \\
\hline
\end{tabular}

${ }^{a}$ Upstream of Nuclear Power Demonstration (NPD) and Chalk River Laboratories (CRL) sites, 1993 (Rowan et al. 1998)

b Downstream of NPD and CRL, 1994 (Rowan 2013)

${ }^{c}$ Downstream of NPD and CRL, 2009-2011 (Rowan et al. 2013) 
Table 2 Cesium bioaccumulation factors BAFs $\left(\mathrm{L} \mathrm{kg}^{-1}\right)$ for invertebrates from ecosystems with federal nuclear sites compared to predictions from Eq. 2. Observations are in good agreement with predictions except for deposit feeding insects from the Ottawa River that reflect historical sediment contamination and inter-tidal algae from the Bay of Fundy

\begin{tabular}{|c|c|c|c|c|c|c|}
\hline \multirow[t]{2}{*}{ Lake } & \multirow[t]{2}{*}[\mathrm{K}]{$\left(\mathrm{mg} \mathrm{L}^{-1}\right)$} & \multicolumn{5}{|l|}{ Cesium BAFs } \\
\hline & & Zooplankton & Molluscs & Insects & Crustaceans & Equation 2 \\
\hline Ottawa River ${ }^{\mathrm{a}}$ & 0.64 & $196 \pm 27$ & $213 \pm 70$ & $367 \pm 47$ & $913 \pm 110$ & 833 \\
\hline Ottawa River ${ }^{\mathrm{b}}$ & 0.64 & $191 \pm 19$ & & & $2116 \pm 169$ & 833 \\
\hline Ottawa River ${ }^{\mathrm{c}}$ & 0.64 & & $274 \pm 40$ & $3474 \pm 608$ & $1073 \pm 260$ & 833 \\
\hline Perch Lake & 1.5 & & & & & 506 \\
\hline Lower Bass Lake & 1.0 & $148 \pm 22$ & & $409 \pm 25$ & & 642 \\
\hline Winnipeg River & 2.2 & & & & & 402 \\
\hline Lake Huron & 1.0 & & & & & 642 \\
\hline Lake Ontario & 1.4 & & & & & 518 \\
\hline St. Lawrence River & 1.5 & & & & & 500 \\
\hline Bay of Fundy & 343 & & $14 \pm 1$ & & $19 \pm 3$ & 21 \\
\hline
\end{tabular}

${ }^{a}$ Upstream of Nuclear Power Demonstration (NPD) and Chalk River Laboratories (CRL) sites, 1993 (Rowan et al. 1998)

b Downstream of NPD and CRL, 1994 (Rowan 2013)

c Downstream of NPD and CRL, 2009-2011 (Rowan et al. 2013)

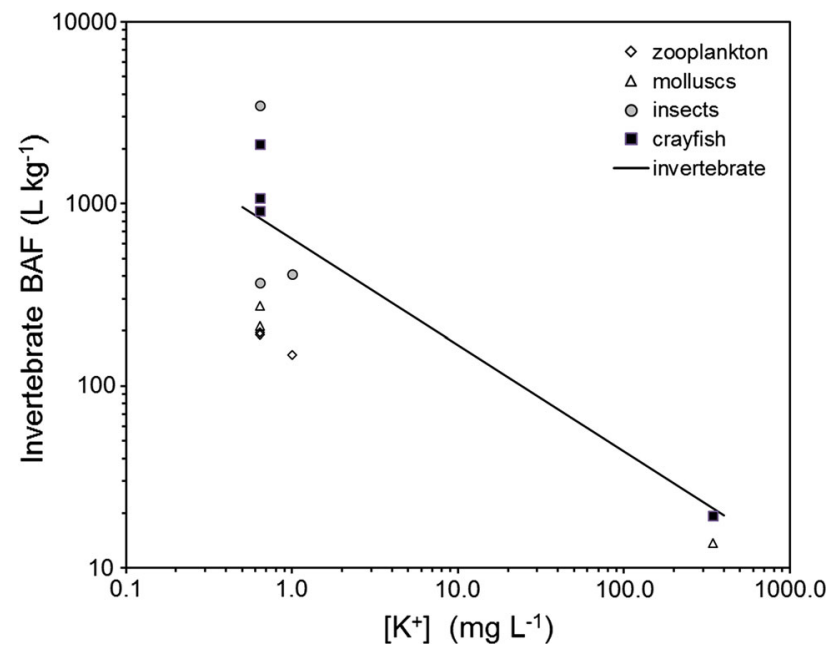

Fig. 2 Bioaccumulation of cesium by invertebrates at federal nuclear sites as a function of dissolved potassium, with predictions plotted for invertebrates [Eq. (2)]

systems were observed earlier (Rowan and Rasmussen 1994).

\section{Bioaccumulation of cesium by aquatic invertebrates}

Bioaccumulation factors for invertebrates are available only for the Ottawa River, Lower Bass Lake, and Bay of Fundy (Table 2; Fig. 2). Bioaccumulation factors for filter feeders (zooplankton and molluscs) are lower than predicted from Eq. (2) by about fourfold. Bioaccumulation factors for aquatic insects are about twofold lower than predictions of Eq. (2), with the exception of deposit feeding aquatic insects near Chalk River Laboratories that ingest

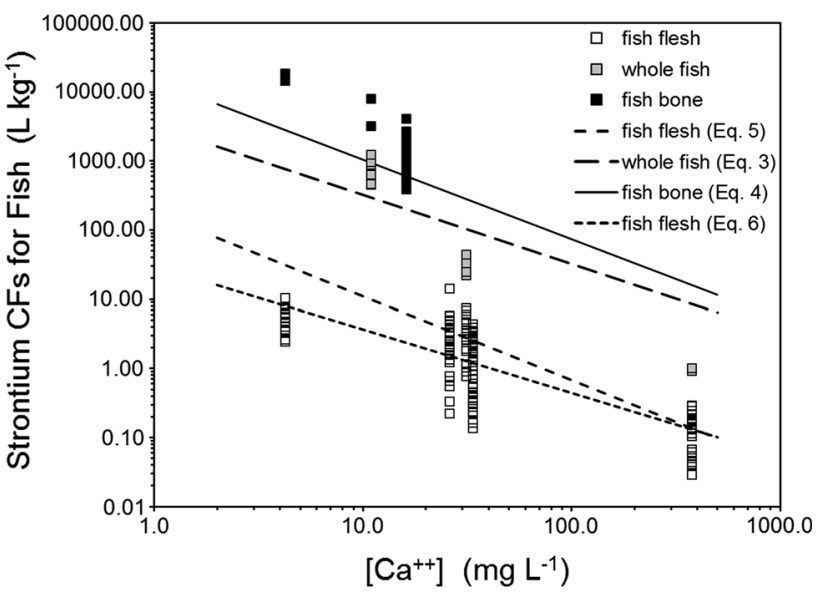

Fig. 3 Bioaccumulation of strontium by fish at federal nuclear sites as a function of dissolved calcium, with predictions plotted for Eq. (3) (whole fish), Eq. (4) (fish bone), Eqs. (5) (fish flesh)

historical sediment contamination. Predictions for crustaceans are in excellent agreement with observations. These trends reflect invertebrate trophic position and the biomagnification of cesium (Rowan et al. 1998).

\section{Bioaccumulation of strontium by fish}

Data on strontium concentrations in fish bone are available for the Ottawa River, Perch Lake, and the Winnipeg River. Bioaccumulation factors for strontium in Ottawa River and Perch Lake fish bone are more than sixfold greater than the predictions of Eq. (4), while those from Winnipeg River fish are about twofold greater than predictions (Fig. 3).

Strontium bioaccumulation factors for fish flesh are available for the Ottawa River, Lake Huron, Lake Ontario, 
Table 3 Descriptive statistics of estimated bioaccumulation factors (BAF parameter, $\mathrm{L} \mathrm{kg}^{-1}$ ) for radiocesium and radiostrontium in Canadian aquatic ecosystems. The analysis involved data from $n=6546$ sampling stations across all Canadian provinces and territories

\begin{tabular}{|c|c|c|c|c|c|c|c|}
\hline \multirow[t]{2}{*}{ BAF parameter } & \multicolumn{7}{|c|}{ Percentiles } \\
\hline & 1 & 5 & 25 & 50 & 75 & 95 & 99 \\
\hline \multicolumn{8}{|l|}{ radiocesium, $137 \mathrm{Cs}$} \\
\hline $\begin{array}{c}\text { Piscivores/ } \\
\text { omnivores }\end{array}$ & 190 & 633 & 1309 & 2741 & 4420 & 7930 & 13400 \\
\hline Range 39.4-47 436 & & & & & & & \\
\hline $\begin{array}{l}\text { Non-piscivores } \\
\text { Range } 12.8-15421\end{array}$ & 62 & 206 & 425 & 891 & 1437 & 2578 & 4356 \\
\hline $\begin{array}{l}\text { Invertebrates } \\
\text { Range: 5.0-9402 }\end{array}$ & 27 & 96 & 207 & 455 & 756 & 1407 & 2456 \\
\hline${ }^{90} \mathrm{Sr}$ & & & & & & & \\
\hline $\begin{array}{l}\text { Fish } \\
\text { Range } 0.06-476\end{array}$ & 0.20 & 0.43 & 0.76 & 1.16 & 2.11 & 8.59 & 26.4 \\
\hline
\end{tabular}

St. Lawrence River, and Bay of Fundy. The bioaccumulation of strontium by fish in freshwater system was more than threefold lower than model predictions [Eq. (5)]; however, models are in agreement in the marine system. To provide better predictions across all conditions, a regression was developed between fish flesh strontium BAF and the calcium concentration of water $\left([\mathrm{Ca}]_{\text {water }}, \mathrm{mg} \mathrm{L}^{-1}\right)$ :

$\log \left(\mathrm{Sr} \mathrm{BAF}_{\mathrm{ff}, \mathrm{ww}}\right)=1.482-0.919 \log [\mathrm{Ca}]_{\text {water }}$,

$r^{2}=0.615, \mathrm{SE}_{\text {est }}=0.392, n=133$,

where strontium $\mathrm{BAF}_{\mathrm{ff}, \mathrm{ww}}$ is the fish flesh strontium $\mathrm{BAF}$ (wet weight, $\mathrm{L} \mathrm{kg}^{-1}$ ). These data and predictions of Eq. (6) are in agreement (generally within less than twofold uncertainty; Fig. 3).

Only three values for strontium bioaccumulation factors for whole fish were available, and for Perch Lake and the St. Lawrence River, predictions of Eq. (3) are within about threefold, but for Bay of Fundy fish, predictions are more than eightfold too high.

Although strontium concentrations are highest in fish bone, the skeleton and other ossified tissues (e.g., skin) contribute less than $15 \%$, conservatively, to the body mass of fish (Krumholz 1956; Rottiers 1993). Thus, soft tissues contain most of the strontium burden, and contribute most to the whole-body strontium activity in fish (Yankovich et al. 2010).

\section{Models selected to produce risk maps}

Widely used cesium and strontium bioaccumulation models generally make reasonable predictions for aquatic biota at federal nuclear sites. For cesium, bioaccumulation by fish in Lake Huron and Ontario tends to be greater than predictions. It is possible that higher than expected bioaccumulation factors for Lakes Huron and Ontario reflect greater potential for trophic magnification in these ecosystems with longer and less efficient food webs, as earlier data show similar patterns (Rowan and Rasmussen 1994). Predictions of cesium bioaccumulation by invertebrates reflect invertebrate trophic position and the biomagnification of cesium at lower trophic levels (Rowan et al. 1998). On the basis of this analysis, Eqs. (1) and (2) appear suitable to assess bioaccumulation risk for Canadian aquatic environments. For piscivores, these models predict cesium accurately, with about twofold uncertainty. For more conservative risk predictions of bioaccumulation factors, results may be adjusted to reflect the upper $95 \%$ confidence limits.

Strontium bioaccumulation models for fish are more problematic, with larger discrepancies for bone, fish flesh, and whole fish that appear dependent on the amount of bone, skin, or scales present in the sample (Saxén et al. 2002; Smith et al. 2009). A new relationship between water calcium concentration and the strontium bioaccumulation factor in fish flesh [Eq. (6)] is recommended for Canadian aquatic environments, as it was developed from observations near Canadian nuclear sites and has relatively low uncertainty (two- to threefold).

\section{Radiocesium and radiostrontium bioaccumulation in Canadian aquatic ecosystems}

Bioaccumulation factors for radiocesium in piscivorous and omnivorous fish varied considerably across the Canadian landscape, ranging from $\sim 40$ to $\sim 47500 \mathrm{~L} \mathrm{~kg}^{-1}$. $95 \%$ of values were below $\sim 8000 \mathrm{~L} \mathrm{~kg}^{-1}$ (Table 3). High-risk areas for cesium bioaccumulation are the eastern Arctic and Labrador. Bioaccumulation risk for cesium was lowest in the Prairies (Fig. 4). Patterns in bioaccumulation factors for non-piscivorous fish (Fig. 5) and invertebrates (Fig. 6) reflect those seen for piscivorous/omnivorous fish, albeit lower by factors of $\sim 3$-fold and 6- to 8-fold, respectively, as predicted by trophic relationships of these organisms. Strontium bioaccumulation factors ranged between 0.06 and $476 \mathrm{~L} \mathrm{~kg}^{-1}$ with $95 \%$ of the values below $\sim 8.5 \mathrm{~L} \mathrm{~kg}^{-1}$. Strontium bioaccumulation factors in fish flesh fall below unity at $[\mathrm{Ca}]_{\text {water }}>41 \mathrm{mg} \mathrm{L}^{-1}$, present at $\sim 40 \%$ of monitoring stations modeled herein (Table 1).

Bioaccumulation risk was generally low $\left(<5 \mathrm{~L} \mathrm{~kg}^{-1}\right)$ throughout most of Canada with notable regional exceptions in the eastern Arctic, Labrador, the subarctic west of Hudson Bay, and northwestern British Columbia (Fig. 7). Cesium and strontium bioaccumulation risk is strongly affected by regional geology, which determines concentrations of competitively inhibiting cations potassium and 


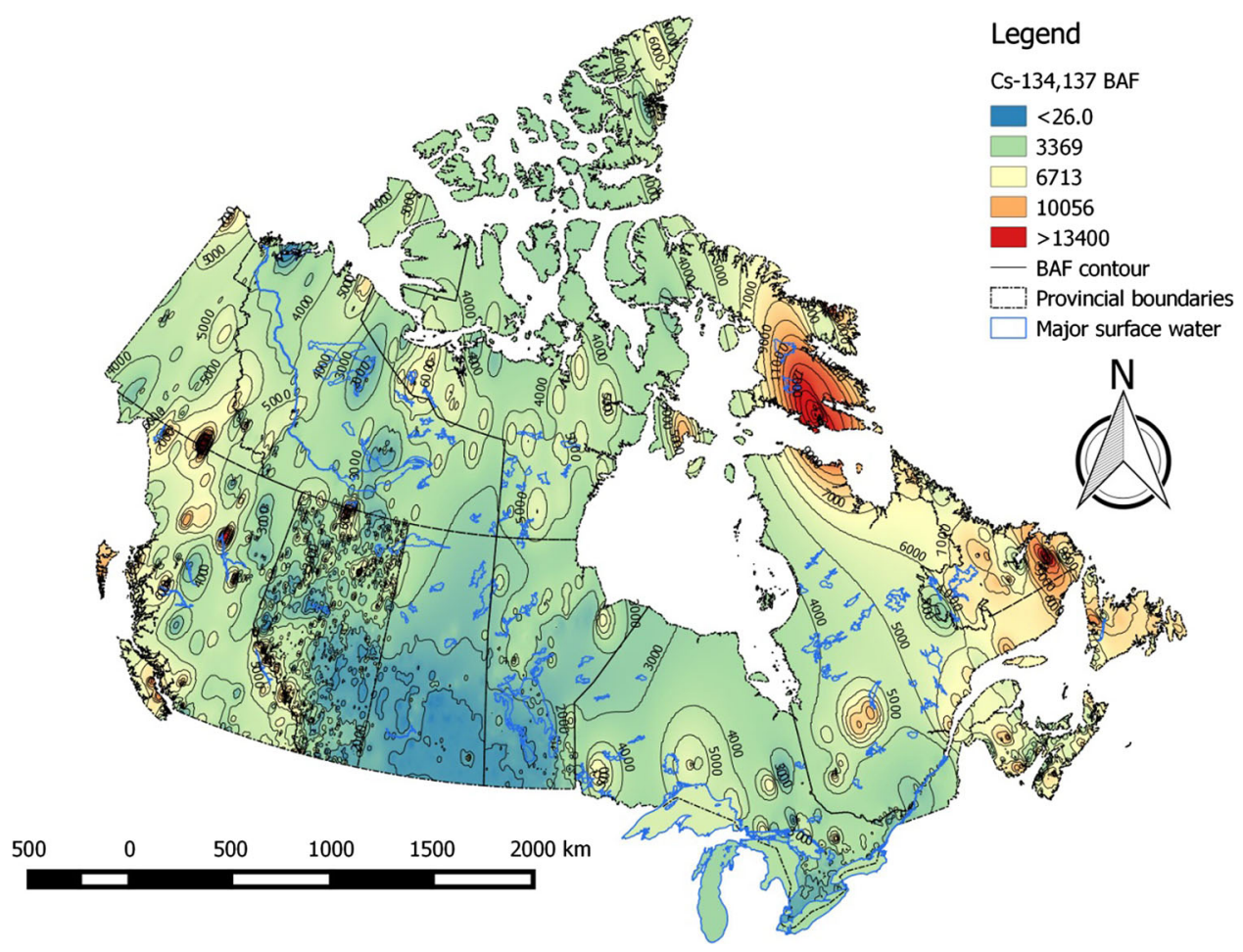

Fig. 4 Bioaccumulation (BAF) risk contour map for radiocesium in flesh of piscivorous and omnivorous fish in Canadian aquatic ecosystems

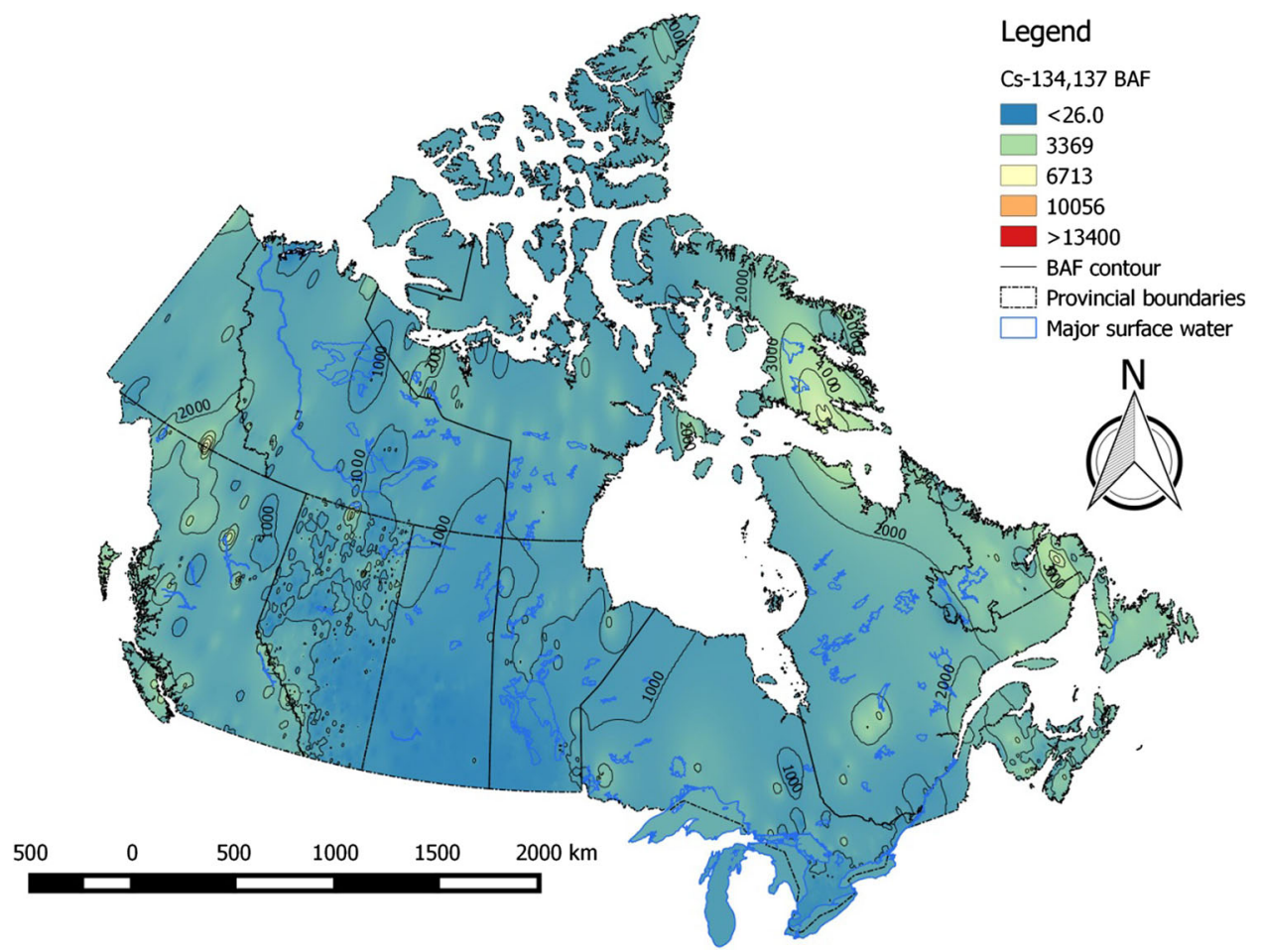

Fig. 5 Bioaccumulation (BAF) risk contour map for radiocesium in flesh of non-piscivorous fish in Canadian aquatic ecosystems 


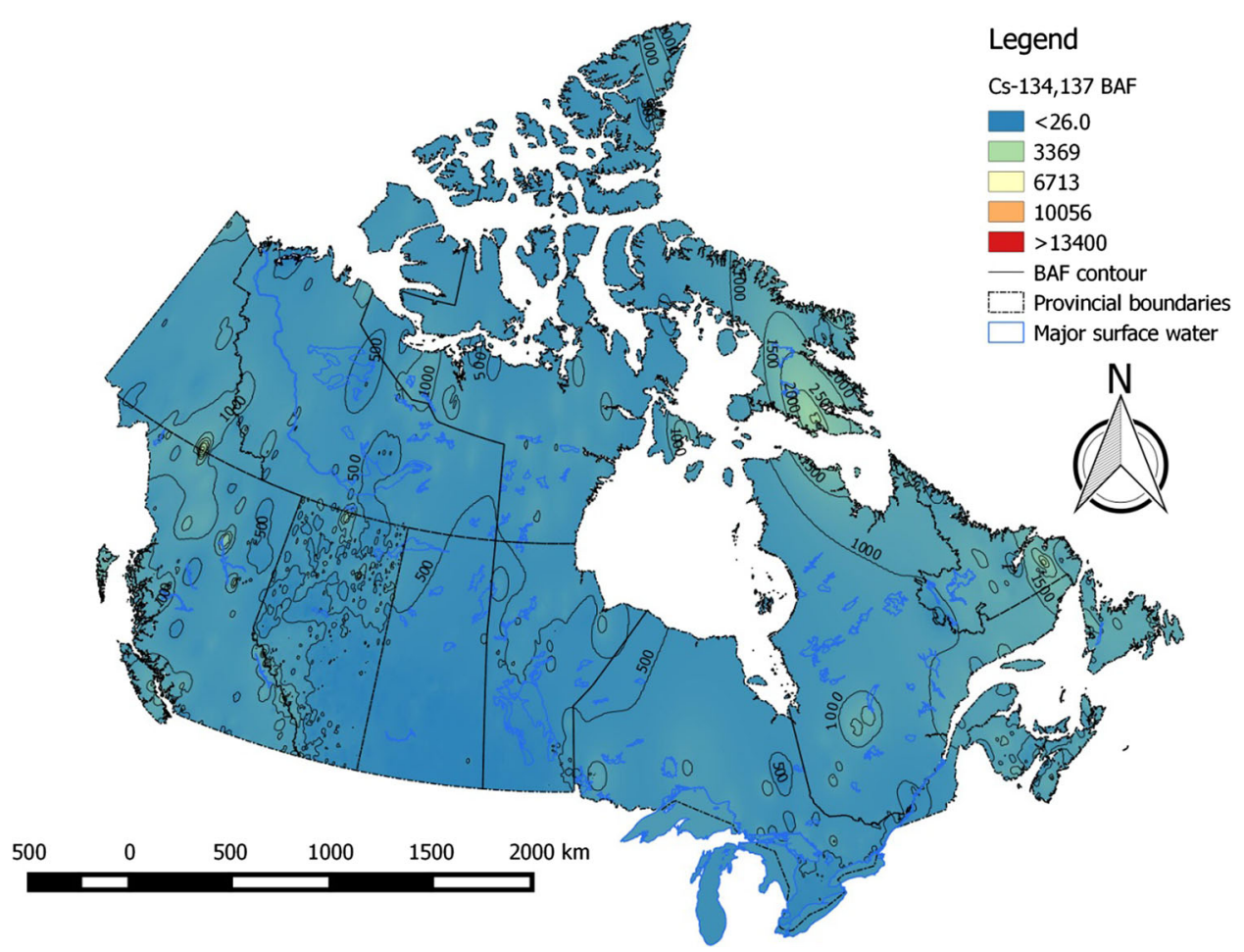

Fig. 6 Bioaccumulation (BAF) risk contour map for radiocesium in invertebrates in Canadian aquatic ecosystems

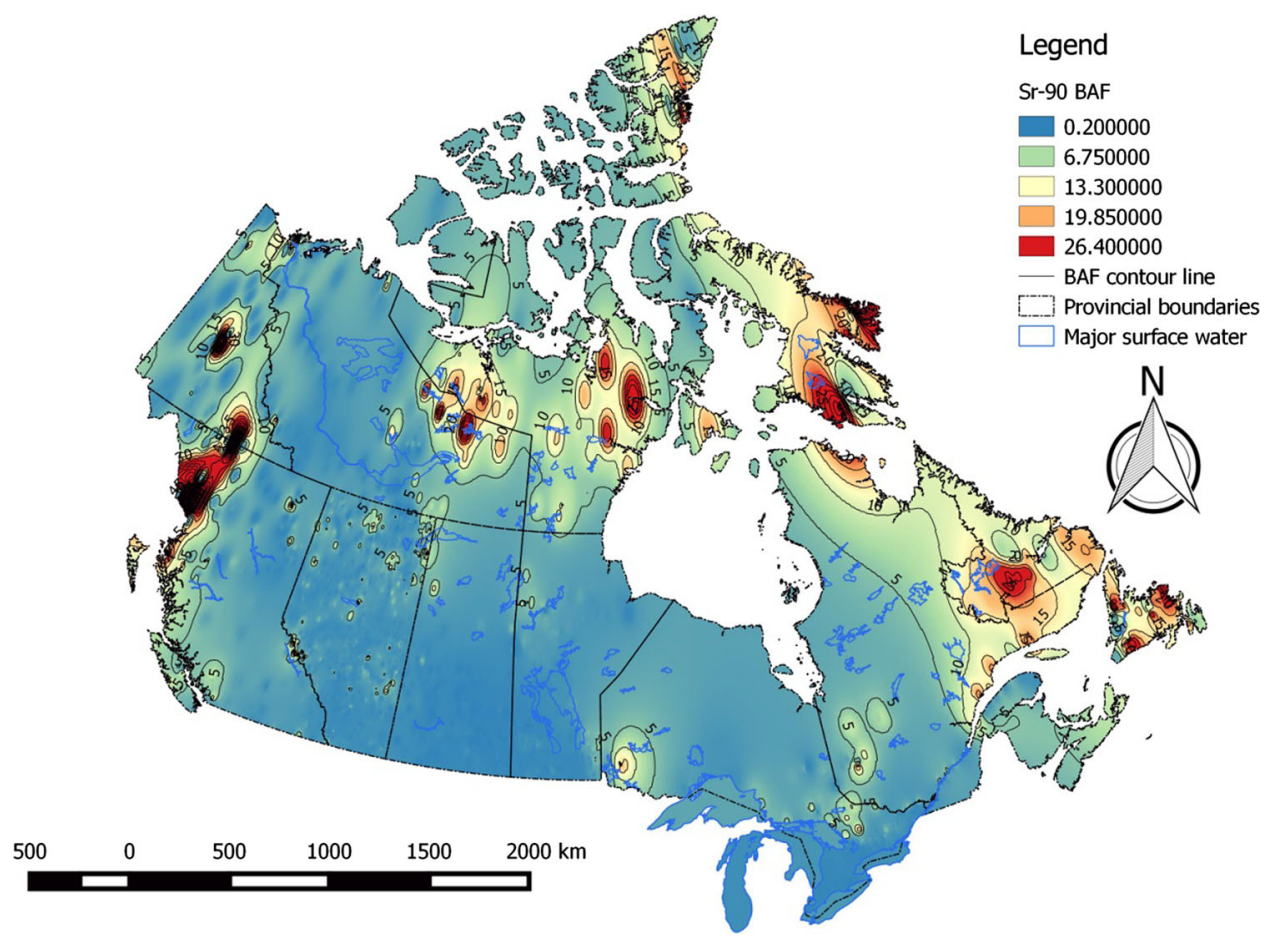

Fig. 7 Bioaccumulation (BAF) risk contour map for radiostrontium in fish flesh in Canadian aquatic ecosystems 
calcium in surface waters. Marine and estuarine ecosystems, which typically exhibit potassium and calcium concentrations in excess of $220-250 \mathrm{mg} \mathrm{L}^{-1}$, risk from bioaccumulation of radiocesium and radiostrontium is predicted to be universally low, with BAFs below 100-fold and well below unity for radiocesium and radiostrontium, respectively.

\section{CONCLUSION}

Widely used cesium bioaccumulation models generally make reasonable predictions for aquatic biota at Canadian nuclear sites, with unexplained variability likely due to trophic position and biomagnification. Strontium bioaccumulation models for fish are more problematic, with larger discrepancies for bone, fish flesh, and whole fish that appear dependent on the amount of bone, skin, or scales present in the sample. A new relationship between the strontium bioaccumulation factor in fish flesh and dissolved calcium was developed from observations at federal nuclear sites. The use of these models and surface water chemistry to predict bioaccumulation factors for radiocesium and radiostrontium provides a useful risk assessment tool that has application to the siting of SMRs and other nuclear reactors, rapid assessment of risk from nuclear accidents, and ecosystem vulnerability.

The use of a single bioaccumulation factor to describe radiocesium and radiostrontium in national and international regulation (CSA 2014; IAEA 2010, p. 472; ERICA $2015)$ is an unnecessary simplification that does not accurately describe spatial variation. The separation of freshwater and marine ecosystems in regulatory standards with respect to radiocesium and radiostrontium is arbitrary as the processes responsible for bioaccumulation are universal across all aquatic ecosystems and predictive models summarized herein perform well along the entire freshwatermarine continuum.

Low calcium and potassium surface waters are at much greater risk from releases of radiocesium and radiostrontium to the environment and many of these vulnerable ecosystems are found in northern regions where indigenous populations are more dependent on wildlife for food. Freshwater fish in these regions are at much greater risk from radiocesium and radiostrontium contamination than are marine fish and mammals in adjoining marine environments due to the much lower potential for bioaccumulation in high calcium and potassium water. In general, marine ecosystems are insensitive to releases of radiocesium and radiostrontium and siting of SMRs in coastal areas would be preferable from a health risk perspective.
Acknowledgements With utmost gratitude we acknowledge the assistance by our contacts in provincial and federal government agencies, whose work on our data requests was invaluable for completion of this manuscript. In no particular order, we were assisted by Lana Miller (B.C. Ministry of Environment), Doreen LeClair (Alberta Environment and Parks), Brian Wiebe (Manitoba Sustainable Development), Pam Minifie (Saskatchewan Water Security Agency), Philip Chau, Kerry Pippy, Minzhen Su, (Environment Canada), Sarah Beattie, Barb Wojtaszek, Doug Tate (Parks Canada), Jonathan Mesher (Aboriginal Affairs and Northern Development Canada), and Michael Paterson (IISD-ELA). Last but not least, Stephanie Walsh and Sebastian Boucher assisted substantially with data extraction and assembly into working datasets.

Open Access This article is distributed under the terms of the Creative Commons Attribution 4.0 International License (http:// creativecommons.org/licenses/by/4.0/), which permits unrestricted use, distribution, and reproduction in any medium, provided you give appropriate credit to the original author(s) and the source, provide a link to the Creative Commons license, and indicate if changes were made.

\section{REFERENCES}

Balasubramaniam, A.M., R.I. Hall, B.B. Wolfe, J.N. Sweetman, and X. Wang. 2015. Source water inputs and catchment characteristics regulate limnological conditions of shallow subarctic lakes (Old Crow Flats, Yukon, Canada). Canadian Journal of Fisheries and Aquatic Sciences 72: 1058-1072.

Chant, L., Hartwig, D., and Totland, M. 2000. Site specific aquatic transfer factors for CANDU sites in Canada. AECL RC-2457.

Chen, J. 2013. Evaluation of radioactivity concentrations from the Fukushima nuclear accident in fish products and associated risk to fish consumers. Radiation Protection and Dosimetry 157: 1-5.

Chowdhury, M.J., and R. Blust. 2001. A mechanistic model for the uptake of waterborne strontium in the common carp (Cyprinus carpio L.). Environmental Science and Technology 35: 669-675.

CNSC. 2016. Small modular reactors: regulatory strategy, approaches and challenges. Ottawa, ON: Canadian Nuclear Safety Commission.

CSA. 2014. Guidelines for calculating derived release limits for radioactive material in airborne and liquid effluents for normal operation of nuclear facilities. Mississauga, ON: C.S. Association. Canadian Standards Association.

ERICA Assessment Tool. 2015. Norwegian Radiation Protection Authority, from http://www.erica-tool.com/erica/.

Farrell, J., and S.E. Campana. 1996. Regulation of calcium and strontium deposition on the otoliths of juvenile tilapia, Oreochromis niloticus. Comparative Biochemistry and Physiology Part A 115: 103-109.

Gallahar, N., and M. Kingsford. 1996. Factors influencing $\mathrm{Sr} / \mathrm{Ca}$ ratios in otoliths of Girella elevata: an experimental investigation. Journal of Fish Biology 48: 174-186.

Guthrie, J., O. Acres, and W. Dunford. 1986. Radioactivity levels in Winnipeg River fish at the whiteshell nuclear research establishment near Pinawa, Manitoba: 1963-1978. Chalk River, ON: Atomic Energy of Canada Limited.

Guthrie, J., Acres, O., and Paul, G. 1974. Monitoring of effluent entering the Winnipeg River from the Whiteshell Nuclear Research Establishment in the period 1963-1972. Environmental Surveillance Around Nuclear Installations: 353.

Hakanson, L., T. Andersson, and A. Nilsson. 1992. Radioactive caesium in fish in Swedish lakes 1986-1988-general pattern 
related to fallout and lake characteristics. Journal of Environmental Radioactivity 15: 207-229.

IAEA. 2010. Handbook of parameter values for the prediction of radionuclide transfer in terrestrial and freshwater environments. IAEA TRS-472. Vienna: International Atomic Energy Agency.

Kessides, I.N. 2012. The future of the nuclear industry reconsidered: risks, uncertainties, and continued promise. Energy Policy 48: 185-208.

Krumholz, L.A. 1956. Observations on the fish population of a lake contaminated by radioactive wastes. Bulletin of the AMNH; v. 110, article 4, TV Authority and UAE Commission.

Kryshev, A. $2006 .{ }^{90} \mathrm{Sr}$ in fish: a review of data and possible model approach. Science of the Total Environment 370: 182-189.

Lee, D., T. Chaput, A. Miller, and C. Wills. 2014. Edibility of sport fishes in the Ottawa River near Chalk River Laboratories. AECL Nuclear Review 2: 73-84.

Neville, D.R., A.J. Phillips, R.D. Brodeur, and K.A. Higley. 2014. Trace levels of Fukushima disaster radionuclides in East Pacific albacore. Environmental Science and Technology 48: 4739-4743.

Nielsen, S.P. 2004. The biological role of strontium. Bone 35: 583-588.

Ophel, I.L., Fraser, C.C., and Judd, J.M. 1971. Strontium concentration factors in biota and bottom sediments of a freshwater lake. EUR-4800 (vols. 1 and 2). Atomic Energy of Canada Ltd., Chalk River, ON.

Pinder, J.E., D.J. Rowan, J.B. Rasmussen, J.T. Smith, T.G. Hinton, and F. Whicker. 2014. Development and evaluation of a regression-based model to predict cesium concentration ratios for freshwater fish. Journal of Environmental Radioactivity 134: 89-98.

Pinder, J.E., D.J. Rowan, and J.T. Smith. 2016. Development and evaluation of a regression-based model to predict cesium-137 concentration ratios for saltwater fish. Journal of Environmental Radioactivity 152: 101-111.

Poston, T.M., and D.C. Klopfer. 1988. Concentration factors used in the assessment of radiation dose to consumers of fish: a review of 27 radionuclides. Health Physics 55: 751-766.

Rottiers, D.V. 1993. Relationship between the amount of bone, major cations, and body size in Atlantic salmon, Salmo salar. Copeia: 440-446.

Rowan, D. 2013a. Bioaccumulation factors and the steady state assumption for cesium isotopes in aquatic foodwebs near nuclear facilities. Journal of Environmental Radioactivity 121: 2-11.

Rowan, D.J., L.A. Chant, and J.B. Rasmussen. 1998. The fate of radiocesium in freshwater communities - why is biomagnification variable both within and between species? Journal of Environmental Radioactivity 40: 15-36.

Rowan, D.J., Chouhan, S., and Stuart, M. 2013. A qualitative and quantitative evaluation of revised IAEA environmental transfer parameters (TRS-472) with respect to the CSA N288.1. COG 09-3020.

Rowan, D.J., and J.B. Rasmussen. 1994. Bioaccumulation of radiocesium by fish: the influence of physicochemical factors and trophic structure. Canadian Journal of Fisheries and Aquatic Sciences 51: 2388-2410.

Saxén, R., Rissanen, K., and Koskelainen, U. 2002. Distribution of ${ }^{137} \mathrm{Cs}$ in tissues and organs of fishes from Finnish lakes and the Baltic Sea. In Proceedings from the International Conference on Radioactivity in the Environment, eds. P. Strand, P. Børretsen, and T. Jølle. CD appendix. Norwegian Radiation Protection Authority, Østerås.

Smith, J., N. Sasina, A. Kryshev, N. Belova, and A. Kudelsky. 2009. A review and test of predictive models for the bioaccumulation of radiostrontium in fish. Journal of Environmental Radioactivity 100: 950-954.

Smith, J.N., R.M. Brown, W.J. Williams, M. Robert, R. Nelson, and S.B. Moran. 2015. Arrival of the Fukushima radioactivity plume in North American continental waters. Proceedings of the National Academy of Sciences 112: 1310-1315.

Smith, J.T., A.V. Kudelsky, I.N. Ryabov, and R.H. Hadderingh. 2000. Radiocaesium concentration factors of Chernobyl-contaminated fish: a study of the influence of potassium, and "blind" testing of a previously developed model. Journal of Environmental Radioactivity 48: 359-369.

Sonnenberg, H. 2015. Environmental baseline data report. Guelph, ON: Hardrock Project: Surface Water Quality.

Vanderploeg, H.A., D.C. Parzyck, W.H. Wilcox, J.R. Kercher, and S.V. Kaye. 1975. Bioaccumulation factors for radionuclides in freshwater biota. Oak Ridge: Oak Ridge National Lab.

Walther, B.D., and S.R. Thorrold. 2006. Water, not food, contributes the majority of strontium and barium deposited in the otoliths of a marine fish. Marine Ecology Progress Series 311: 125-130.

Waters, C., and R. Didsbury. 2014. Small modular reactors-a solution for Canada's north? AECL Nuclear Review 1: 3-7.

Whicker, F., Garten Jr, C.T., Hamby, D., Higley, K., Hinton, T., Kaplan, D., Rowan, D., and Schreckhise, R. 2007. Cesium-137 in the environment: radioecology and approaches to assessment and management (NCRP Report No. 154). Oak Ridge National Laboratory (ORNL); Oak Ridge National Environmental Research Park.

Yankovich, T., J.V. i Batlle, S. Vives-Lynch, N. Beresford, C. Barnett, K. Beaugelin-Seiller, J. Brown, J. Cheng, D. Copplestone, and R. Heling. 2010. An international model validation exercise on radionuclide transfer and doses to freshwater biota. Journal of Radiological Protection 30: 299.

\section{AUTHOR BIOGRAPHIES}

Lars Brinkmann $(\varangle)$ Ph.D., is a radioecologist at Canadian Nuclear Laboratories, Chalk River. His research focus is on modeling the fate, transport, and bioaccumulation of stable and radioactive elements in support of contaminant risk assessments. He is also interested in contaminants as integrators of ecosystem processes and the use of tracer biokinetics to study these processes.

Address: Environmental Technologies Branch, Canadian Nuclear Laboratories, Chalk River Laboratories, Chalk River, ON K0J 1J0, Canada.

e-mail: lars.brinkmann@cnl.ca

David J. Rowan Ph.D., is a radioecologist at Canadian Nuclear Laboratories, Chalk River. His current research interests are modeling food web biokinetics following pulse releases of radionuclides to aquatic ecosystems, and developing recovery phase parameters and models for the St. Lawrence system.

Address: Environmental Technologies Branch, Canadian Nuclear Laboratories, Chalk River Laboratories, Chalk River, ON K0J 1J0, Canada. 